\title{
ISLAM DAN NEGARA: Otoritas dan Kekuasaan dalam Pemikiran Islam
}

\author{
Helmy Syaifuddin
}

Dosen Fak. Humaniora dan Budaya Universitas Islam Negeri (UIN) Malang

\begin{abstract}
Abstrak
Moslem world at first only understand the concept of religious and political territory; dar al Islam and dar al harb. Since the concept of state-nation as political system entity which modernism brings has covered Islamic nation, there emerges a conceptual and historical tension on the relation between Islam and politics. The presence of state-nation which holds ethnicity as the basic criteria and foundation has taken over religious stand as the attachment of national identity. It is replaced by the emergence of sense of culture and demography as well as nationalism. The idea of state-nation has replaced the idea of Islamic order for nation. This fact leads the swift of the authority and power the leader has. Within the context of tension between Islam and politics, Muhammad Arkoun proposed the solution by redefining the concept of the authority and power. It is to accept the idea of state-nation with its secular view. He argued that political regime of Moslem world after colonialism is de facto secular and controlled by Western paradigm. Therefore, Moslem can revise the idea of secularism and the regime position committed to secularism to be Islamic-based by doing great diffusion, or what Arkoun called as intellectual modernity.
\end{abstract}

Ulul Albab, Vol. 6 No. 1, 2005 


\section{A. Pengantar}

Pengalaman Madinah (l'experience de Medine) seringkali dianggap sebagai cermin realitas konkret dari bentuk pemerintahan dalam Islam. Dalam pengalaman Madinah, terdapat kesatuan otoritas religius yang transendental dan kekuasaaan politis yang temporal dalam diri Muhammad sebagai penguasa pemerintahan. Karena, di Madinahlah dakwah Islam memperoleh perwujudan politiknya yang pertama di mana Muhammad menyatukan kharismanya sebagai Rasul Allah yang membimbing masyarakat beriman (ummah mu'minah) dan kekuasaan untuk memutuskan konflik antara orang beriman-orang kafir serta mengatur strategi perang untuk menang.'

Berangkat dari preseden tersebut, kebanyakan penguasa Muslim sepeninggal Nabi mencoba melegitimasi otoritas mereka melalui Islam. ${ }^{2}$ Artinya, otoritas politik dalam pemerintahan Islam menuntut adanya dasar religius dan legitimasinya harus dikaitkan dengan prinsip tauhid. Tidak ada penguasa Muslim yang berani mengklaim memiliki otoritas yang berdaulat, karena hanya Tuhan saja yang memilikinya. Penguasa hanya mendasarkan otoritasnya pada pandangan bahwa ia menjalankan kehendak Tuhan seperti yang ditetapkan dalam wahyu Islam. Itulah sebabnya muncul klaim bah wa Islam merupakan agama yang tidak memisahkan antara yang rohani dan duniawi, yang material dan yang spiritual. ${ }^{3}$

Pada masa al-Khulafa' al-Rashidun, eksperimen pemerintahan Madinah secara historis tidak mengalami perubahan yang cukup berarti, karena pemerintahan masa itu secara konsep dan praktik merupakan lanjutan dari kepemimpinan Muhammad. Pada era dinasti Umayyah di Damaskus (661-750 M) dan dilanjutkan oleh dinasti Abbasiyyah di Baghdad (750-1258 M), mulai terjadi ketegangan hubungan antara otoritas transendental dan kekuasaan politis. Pada masa tersebut yang berlaku adalah model pemerintahan yanglebih menitikberatkan pada pertimbangan-pertimbangan politis. Pada masa modern, jarak antara otoritas transendental dan kekuasaan politis semakin melebar, akibat dari sekularisme yang hadir bersama negara-bangsa (nation-state) yang diintrodusir oleh Barat.

Sebagaimana diketahui, sejak awal perkembangan Islam sampai setidaknya zaman pramodern, masyarakat Muslim hanya mengenal konsep teritorial politik- 
religius dar al-Islam dan dar al-harb. Pada tingkat institusional, semua wilayah dar al-Islam pada dasarnya merupakan suatu religiously based super-state (negara yang terbentuk atas dasar keimanan) dengan pelaksanaan otoritas yang tersentral. Warga negara Muslim yang mengakui otoritas sentral tersebut membentuk ummah (komunitas), sebuah entitas yang esensinya bersifat religius karena anggota-anggotanya diikat oleh persaudaraan yang harus dilindungi oleh penguasa (khalifah, imam atau sultan) yang absah. Pada era modern, ketika bentuk negara-bangsa sebagai satuan sistem politik yang diusung oleh modernitas melanda negara-negara Islam, lahirlah ketegangan historis dan konseptual mengenai hubungan Islam dan politik. Dalam periode antara penghapusan Kesultanan Uthmaniyah pada 1924 dan munculnya fundamentalisme Islam pada awal 1970an, gagasan negara-bangsa tampaknya menggantikan gagasan tentang tatanan (orde) Islam. ${ }^{4}$ Kehadiran bentuk negara-bangsa yang keberadaannya didasarkan pada kriteria etnisitas, budaya dan wilayah serta bermuara pada nasionalisme diakui telah mengambil alih posisi religius sebagai identitas perekat suatu negara. Antara 1930-an hingga awal 1970-an, negara-bangsa merupakan bentuk legitimasi yang paling diterima di Dunia Arab. Penetrasi negara-bangsa ke dalam negaranegara Islam tersebut akhirnya berdampak pada pergeseran makna otoritas dan legitimasi bagi para pemegang kekuasaan.

Dalam konteks ketegangan antara Islam dan politik pada era modern tersebut, banyak bermunculan gagasan untuk melakukan redefinisi terhadap konsep otoritas dan legitimasi dalam Islam. ${ }^{5}$ Mungkin nama Mohammed Arkoun adalah termasuk salah satu pemilik gagasan yang tidak dapat diabaikan. Selain merupakan pemikir Muslim yang dilahirkan dalam setting budaya Islam, Arkoun juga termasuk orang yang menghabiskan sebagian besar usianya di Barat, tempat konsep negara-bangsa itu lahir dan berkembang. ${ }^{6}$ Kualifikasi ini setidaknya menjadilegitimasi bagi pikiran-pikirannya untuk disimak. Oleh karena itu, tulisan ini bermaksud mengelaborasi pemikiran Arkoun mengenai makna otoritas yang sedang diperdebatkan tersebut melalui sebuah pertanyaan: bagaimana wilayah otoritas spiritual dan politik ditentukan dalam Islam? 


\section{B. Ada Apa dengan Arkoun?}

Perlu diinformasikan di sini bahwa Arkoun sesungguhnya bukanlah pakar dalam bidang ilmu politik. Tetapi, karena kepeduliannya terhadap spektrum pemikiran Islam yang luas dan menyeluruh, maka Arkoun menyempatkan diri untuk membahas persoalan politik itu, terutama dalam kaitannya dengan Islam melalui model dan gaya yang khas dirinya. ${ }^{7}$ Menurutnya, hubungan antara Islam dan politik dapat dianalisis melalui dua pendekatan yang berkelanjutan. Pertama, pendekatan historis konvensional yang akan menghasilkan uraian deskriptif. Kedua, pendekatan pemikiran dan perenungan kembali atas persoalan yang pernah muncul dalam sejarah percaturan Islam dan politik yang akan menghasilkan Islam sebagai agama "yang dipikirkan kembali" dalam rangka pengetahuan kontemporer. $^{8}$

Melalui pendekatan historis dapat diamati proses kehadiran Islam dan perkembangannya yang pertama serta keterkaitannya dengan undang-undang ideal yang meliputi prinsip, kaidah dan tindakan keteladanan yang diajukan oleh Muhammad dan sahabat-sahabatnya sekitar tahun 610-661 M. Semua rangkaian peristiwa itu oleh masyarakat Muslim dianggap sebagai pengungkapan yang benar dan dapat dipercaya datang dari Islam, sehingga anggapan itu berdampak pada kesimpulan bahwa negara dengan model Islam merupakan tipe ideal bagi masyarakat Muslim. Selanjumya, melalui pendekatan pemikiran dan perenungan kembali dapat ditunjukkan bahwa keterkaitan antara kekuasaan keagamaan dan kekuasaan politis telah melewati serangkaian pengalaman yang kaya, yang tidak memungkinkan untuk ditetapkan bahwa keterkaitan Islam dan politik sebagai negara model Islam. Munculnya gagasan negara Islam adalah akibat dari situasi baru yang terjadi belakangan, yaitu pada permulaan tahun 1920-an dan mengalami titik kulminasi pada tahun 1950 berupa munculnya gerakan pembebasan tanah air di negara-negara Asia dan Afrika. ${ }^{9}$

Agar penjelasan tentang hubungan antara Islam dan politik dalam pemikiran Islam dapat disampaikan secara lebih baik, Arkoun memanfaatkan model analisis semiotik. Dalam ikhtiarnya itu, Arkoun menyebutkan ada tiga aktan (actant; pelaku; pemegang peran) yang saling terkait dan menjadi kata kunci dalam memahami hubungan otoritas dan kekuasaan dalam Islam, yaitu aktan pertama (l'actant premier) berarti Allah, aktan perantara (l'actant mediateur) berarti para nabi

Ulul Albab, Vol. 6 No. 1, 2005 
dan aktan ketiga (le troisieme actant) berarti manusia. ${ }^{10}$ Aktan pertama pada saat yang bersamaan berfungsi juga sebagai penutur bahasa, subjek, pengirim dan penerima. Fungsi tersebut menjelaskan bagaimana Allah menata seluruh spektrum makna-Nya melalui kalam dan perbuatan-Nya. Secara analogis, hal tersebut juga terjadi pada diri dua aktan lainnya dalam aktivitas pragmatis mereka. Para nabi adalah subjek perantara yang berucap dengan bahasa yang berlaku dalam lingkungannya, sehingga dari sudut pandang tertentu mereka bertindak sebagai pengirim sekaligus penerima. " Contoh konkret dari hal ini adalah pernyataan Nabi: "Taatilah Allah dan taatilah aku (Rasul-Nya)," yang mengingatkan Muslim bahwa sesungguhnya Nabi menjadikan dirinya sebagai sosok yang harus ditaati dan pada saat yang sama ketaatan itu merupakan bukti ketaatan dan ketakwaan kepada Allah. Di sini ada keterkaitan antara ketaatan kepada Allah dan kataatan kepada Rasul yang diciptakan oleh struktur semiotis. Akhirnya, menurut Arkoun, bentuk perintah maupun larangan Allah (aktan pertama) yang disampaikan oleh Nabi (aktan perantara) ketika diterima oleh manusia (aktan ketiga) akan memunculkan kelompok orang yang disebut alQur'an dengan istilah mukmin dan kafir. Kategori mukmin dan kafir ini, lanjut Arkoun, memiliki pengaruh besar terhadap perkembangan politik, sosial, dan ekonomi jika hal itu tidak semata-mata dipahami secara statis sebagai istilah yang hanya berfungsi dalam bidang teologi. ${ }^{12}$ Demikianlah, struktur hierarkis yang terdiri dari tiga aktan itu setidaknya telah memberikan gambaran awal mengenai dialektika Islam dan politik.

Bertolak dari pandangan tersebut, tampaknya Arkoun terus mencoba mencari pemahaman baru tentang Islam dan masyarakat Muslim dengan menggunakan teori-teori yang berkembang di Barat modern. Jalan yang ditempuh oleh Arkoun tersebut bukan sesuatu yang mengherankan dan tidak perlu disesalkan, mengingat selama tinggal di Perancis (sejak 1954) ia telah banyak belajar dan menekuni berbagai teori dan metodologi ilmu pengetahuan Barat. ${ }^{13}$ Arkoun berpandangan bahwa "penaklukan pemikiran Barat sama sekali tidak mengancam pemikiran dan masyarakat Islam, melainkan penaklukan itu menjadi sarana untuk memahami secara lebih baik mengapa pemikiran Islam sampai terperosok pada kekakuan dan ketertutupan."'14 Dengan menempuh langkah demikian diharapkan muncul suatu pemikiran Islam yang dapat memberikan jawaban atas persoalan yang dihadapi Muslim belakangan ini. Suatu pemikiran 
yang berfungsi membebaskan Muslim dari belenggu yang dibuatnya sendiri, baik secara intelektual maupun politis.

Dalam berbagai studinya mengenai Islam, Arkoun banyak merujuk kepada filosof Perancis seperti Paul Ricoeur, Michel Foucault dan Jaques Derrida ${ }^{15}$ dalam merumuskan pemikirannya. Selain itu, ahli bahasa Swiss Ferdinand de Saussure, ahli semiotika Perancis Roland Barthes, antropolog Perancis Pierre Bourdieu, antropolog Inggris Jack Goody dan ahli sastra Kanada Northrop Frye juga menjadi rujukan Arkoun dalam mengembangkan pandangan-pandangannya. ${ }^{16}$

\section{Konsep dan Format Otoritas dalam Pemikiran Klasik}

Apa yang dimaksudkan dengan otoritas (autorite, al-siyadah al-'ulya) adalah suatu jenis kewenangan yang melekat pada Allah Yang Maha Hidup dan bersabda kepada manusia. Otoritas tersebut (otoritas transendental) melegitimasi kekuasaan politis (pouvoir politique, al-sultah al-siyasiyyah) yang dijalankan oleh Nabi dan para penerusnya. Jadi, otoritas transendental dan kekuasaan politis dalam Islam merupakan dua entitas yang saling berkaitan. ${ }^{17}$ Perwujudan konkret dari keterkaitan itu dapat dilihat pada diri Muhammad. Juga dapat dilihat pada kehadiran Islam itu sendiri yang merupakan reaksi terhadap kekuasaan-kekuasaan sebelumnya yang kemudian digantikan oleh kekuasaan politis Muhammad yang berjalan selaras dengan otoritas yang dimaksudkan. ${ }^{18}$

Persoalan bagaimana otoritas yang melekat pada Allah itu dapat mengintervensi secara permanen pada diri Nabi dapat ditelusuri jawabannya melalui konsep pewahyuan. Boleh dikatakan bahwa diskursus al-Qur'anlah yang menciptakan hubungan persepsi-kesadaran yang terpusat kepada Allah Yang Hidup, Kreatif dan Transenden. Ayat-ayat pendek berikut perlu dipertimbangkan berkenaan dengan tesis tersebut: (1) "Katakanlah: Aku berlindung pada Tuhan manusia...,"19 (2) Bacalah, dengan nama Tuhanmu..." dan (3) "Dan telah Kami turunkan al-Qur'an bagian demi bagian agar engkau dapat membacakannya kepada manusia... katakanlah: berimanlah kepadanya (al-Qur'an itu) atau tidak beriman kepadanya." ${ }^{21}$

Berdasarkan teori semiotika, sebagaimana telah dijelaskan sebelumnya, dalam diskursus al-Qur'an terdapat tiga pendukung, yaitu pembicara-pengarang 
(Allah; aktan pertama), utusan-penyampai (Muhammad; aktan perantara) dan penerima kolektif dari pesan (manusia; aktan ketiga). ${ }^{22}$ Jika diperhatikan ayatayat yang dicontohkan itu, pembicara (Allah) membuat diri-Nya dikenal melalui penggunaan bentuk jamak yang mengagungkan diri (Kami), melalui perintah, peringatan, bentuk penilaian dan lain-lain. Ia memenuhi ruang dengan ekspresi kehendak yang maha kuat, pengetahuan yang tak terbatas dan penguasaan berdaulat atas manusia. Semua yang dikatakan-Nya menegaskan transendensi dan keagungan diri-Nya serta mengaitkannya dengan keagungan engkau yang diajak bicara. Bentuk mengajak bicara ini dipilih dan ditentukan untuk mengangkat engkau pada harga diri sebuah $A k u$ yang menyadari kesatuan fisiknya dengan harga diri pembicara. Jadi, kesan yang segera muncul adalah kesan makhluk hidup yang memperkenankan diri untuk didekati dan mengekspresikan diri dalam bahasa. ${ }^{23}$

Sementara itu, rasul (utusan) bukanlah penyampai pasif bagi ujaran-ujaran yang diterimanya. Penggunaan imperatif dalam bahasa Arab dari bentuk langsung setelah kata kerja "qala" (katakanlah) menyebabkan sang utusan dapat mengekspresikan diri seolah-olah ia sendirilah pembicaranya. Perpindahan dari fungsi penyampai (Rasul) menuju fungsi pembicara berarti pemikulan tanggung jawab atas dialog, sehingga juga perluasan dalam tataran makhluk menuju tataran yang mengekspresikan diri. Dengan kata lain, Rasul yang menjadi sasaran pesan dimungkinkan bagi dirinya menjadi pembicara yang berpartisipasi, dalam berbagai tingkat, dalam $A k u$-nya sang pembicara-pengarang. ${ }^{24} \mathrm{Hal}$ itu juga berlaku pada aktan ketiga, ketika manusia menyampaikan ayat al-Qur'an kepada sesamanya.

Demikianlah pengertian wahyu yang "diturunkan"Allah kepada Muhammad hingga berhasil membangun otoritas pada diri nabi-Nya. Dengan demikian, secara tegas dapat dinyatakan bahwa pada masa $\mathrm{Nabi}$, otoritas didasarkan pada ketegasan makna yang diambil dari wacana semantik, sintaksis dan struktur retorika alQur'an yang secara langsung dirasakan lewat tindakan karismatik-historis Nabi. ${ }^{25}$

Setelah Nabi wafat, representasi total dari otoritas yang hidup itu pecah ke dalam dua proses perkembangan, yaitu (1) al-Qur'an dan al-Hadith, yang mulai dihimpun, dibukukan dan diinterpretasikan sehingga menghasilkan korpus dari tradisi skriptural besar dan (2) negara, yang menggunakan wajah otoritas untuk menerapkan sebuah praksis politik dan melakukan kontrol terhadap kekuatan budaya secara terus-menerus sehingga memberikan dampak bagi tradisi 
skriptural. ${ }^{26}$ Kedua proses perkembangan itu berjalan sejajar meski penjagaannya dilakukan oleh entitas yang berbeda. Yang pertama dipertahankan oleh fugaha (para ahli hukum) dan yangkedua oleh penguasa negara yang menjadikan otoritas sebagai legitimasi pemerintahannya.

Pada regim al-Khulafa' al-Rashidun, anggota kolektif sahabat serta kondisi kultur di Madinah membantu mempertahankan hierarki nilai yang dominan pada masa Nabi. Akan tetapi, kemudian terjadi pertarungan antartradisi masyarakat Arab dan lahir visi baru yang terdapat dalam al-Qur'an hatta membawa pada kenyataan bahwa 'Umar, Uthman dan 'Ali terbunuh. Hal itu menunjukkan bahwa fungsi otoritas sebagai suatu usaha pembenaran religi (transendental)dalam rangka mengontrol kebrutalan naluri manusia (temporal) temyata mengalami keterbatasan. Dampak langsung yang diterima dari keterbatasan itu adalah negara yang dibangun oleh dinasti Umayyah dan selanjutnya dinasti 'Abbasiyyah tidak lain merupakan hasil dari kekerasan berdarah. Artinya, kelompok-kelompok yang memegang kekuasaan mencari legitimasinya dengan menjadikan kekerasan sebagai otoritas untukmenjaga stabilitas sosial-politik.

Tampaknya ada tradisi baru yang dihidupkan oleh dinasti Umayyah dan 'Abbasiyyah dalam mencari legitimasi pemerintahan. Menurut Arkoun, tradisi itu tidak lebih merupakan tradisi ortodoks sebagai hasil kolaborasi antara mayoritas ulama dengan negara. ${ }^{27}$ Mereka membentuk konsep, melalui institusi yang disebut ijtihad, bahwa seorang khalifah, imam ataupun malik merupakan representasi dari suatu otoritas suci. ${ }^{28}$ Akhimya, konsep otoritas lebih bergantung pada ijtihad para ahli sejarah dan ahli hukum (jurist, fagih) yang mengabdi pada dinasti. Melalui para ahli hukum ini khalifah, malik ataupun imam terlegitimasi menjadi sesuatu yang sakral dan merupakan perwujudan simultan otoritas dan kekuasaan. Argumentasi yang mendukung tesis ini adalah bahwa baik khalifah, malik maupun imam masing-masing memiliki tujuan membimbing penerapan secara ketat shari'ah yang telah disakralkan dan ditransendensikan oleh para ahli hukum itu. Dengan perkataan lain, otoritas penguasa didasarkan pada ketaatannya kepada shari'ah. Meskipun ia pemimpin politik komunitas Islam yang mutlak, tetapi tidak memiliki hak untuk membuat undang-undang (hak itu ada pada fugaha). Kewenangannya hanyalah menjalankan shari'ah. Namun dalam praktik selanjutnya, para penguasa Islam menyimpang dari prinsip ini dengan memperkenalkan siyasah yang otonom yang menjadikan mereka berdaulat. ${ }^{29}$

Ulul AVbab, Vol. 6 No. 1, 2005 
Semua teori yang dielaborasi oleh para ahli hukum tersebut yang mempertaruhkan nama agama itu pada dasarnya dalam rangka menjaga kontinuitas model yang konon harus ditentukan di dalam al-Qur'an dan dicontohkan oleh aktivitas Nabi. Artinya, dalam berijtihad, sebagai pondasi intelektual otoritas, para ahli hukum mendasarkan pada postulat yang memiliki konsekuensi yang harus dibuat eksplisit, seperti (1) Untuk dapat dipercaya, ijtihad yang dilakukan para ahli hukum harus didasarkan pada pengetahuan tentang tata bahasa Arab, leksikografi, semantik dan retorika yang sempurna (inilah sebabnya mengapa semua kaidah dalam usul al-fiqh diawali dengan pendahuluan yang membahas masalah-masalah linguistik), (2) karena usul al-fiqh diterima sebagai disiplin yang otoritatif, maka para penulis harus menguasai pengetahuan (bahasa) Arab yang sempurna seperti yang disyaratkan untuk menghindari hal-hal yang menyebabkan revisi atas hasil karyanya, (3)disiplin usul al-fiqh didefinisikan oleh para ahli hukum sebagai metodologi dan dalam perkembangannya berkaitan dengan epistemologi hukum, sehingga dapat diyakini (kebenarannya) bahwa semua ahkam benarbenar diturunkan dari teks-teks suci yang mengekspresikan hukum otentik yang berasal dari Allah semata (itulah sebabnya mengapa semua shari 'ah merupakan hukum yang diturunkan dari Allah, disakralkan dan transenden, tidak mungkin mengalami revisi oleh setiap legislator) dan (4) ijma' dan qiyas, juga merujuk kepada kecakapan dalam membaca teks-teks berbahasa Arab. ${ }^{30}$ Demikianlah, sekilas tampak ada upaya serius dari para mujtahid untuk mempertahankan tradisi yang dihidup-hidupkan (the living tradition) pada masa Nabi. Tetapi; justru hal itu menjadi bumerang yang membelenggu pemikiran Islam, secara intelektual maupun politis, sehingga terperosok pada kekakuan dan ketertutupan.

Sekali lagi, semua teori di atas tetap dibenarkan untuk mendeteksi pengaruhnya terhadap model otoritas yang telah diwujudkan dan disakralkan melalui korpus utama yang diklaim oleh tradisi: al-Qur'an, Hadis, Nahj alBalaghah dan karya keagamaan lainnya yang terkumpul dalam antologi. Dari seluruh teks tersebut dapat disimpulkan mengenai tiga tipe gambaran otoritas, yaitu (1) gambaran ideologi yang digunakan untuk menguatkan legitimasi representasi negara yang resmi, atau untuk mengingatkan para penguasa terhadap aturan-aturan ideal yang selalu harus ditiru, (2) gambaran dongeng dan mitologi yang berkaitan dengan konstruksi literatur dari tipe ideal figur otoritas dengan cara memproyeksikan moral dan kemampuan yang dituntutnya ke dalam 
personalitas seperti Muhammad, Abu Bakr,Umar dan Ali, dan (3) otoritas personal terdahulu digunakan untuk membangun sebuah tipe ideal. Ketiga gambaran tersebut merupakan konstruksi berjenjang dari memori kolektif yang diusahakan oleh para ahli historiografi, ulama dan sastrawan. ${ }^{31}$

\section{Otoritas dan Kekuasaan dalam Konteks Masa Kini}

Di antara persoalan krusial yang dihadapi Muslim akibat modernitas adalah hadirnya bentuk negara-bangsa sebagai satuan sistem politik yang berujung pada nasionalisme. Sebelum konsep negara-bangsa ini muncul, yang menjadi dasar identitas perekat suatu negara adalah unsur keimanan. Namun, negara-negara yang mendasarkan pada kedekatan spiritual tersebut tidak sanggup bertahan dihadapan fakta bahwa setiap orang memiliki kesetiaan sekuler berdasarkan kesamaan bahasa, budaya dan wilayah yang disebut nasionalisme. Kini kenyataannya tidak ada lagi di dunia Islam negara yang bukan negara-bangsa. Semua terkesima oleh kekuatan dan efektivitas model negara-bangsa modern.

Metamorfosis negara-negara Islam menjadi negara-bangsa ini tidak terjadi pada ruang hampa. Sesungguhnya ada dua fakta historis yang meniscayakan penerapan model negara-bangsa di tengah-tengah masyarakat Muslim pascakolonialisme. Pertama, penghancuran total negara kekhalifahan Sunni di Baghdad pada 1258 oleh serbuan tentara Mughol. Ketika dinasti Utsmani berusaha membangkitkan kembali sistem khilafah yang secara sentralistis menguasai $d a r$ al-Islam, penguasanya tidak lagi menyebut dirinya khalifah atau imam, tetapi sultan. Jabatan khalifah memang tetap ada, namun hanya sebatas pejabat yang mengurus masalah-masalah keagamaan. Kedua, usaha Ataturk menghapus sistem kesultanan (Utsmani) tersebut pada tahun 1924.

Pada negara-negara Islam sebelum menerima penetrasi dari konsep negarabangsa, bentuk pemerintahannya (baik khilafah, imamah maupun kesultanan) mensyaratkan adanya teritorial politik tertentu yang disebut mamlakah. Secara yuridis dan teologis daerah yang tersentralisir itu disebut dar al-Islam, sementara rakyat yang mengakui kekuasaan pusat itu disebut ummah. Akan tetapi, belakangan negara-negara Islam terkesima oleh model negara-bangsa sebagaimana dipraktikkan oleh sejumlah negara Eropa. Bahkan Iran yang secara eksplisit menyatakan diri sebagai negara Islam, sebenarnya lebih mendasarkan dirinya 
pada ke-Persia-an daripada keislaman. Dengan demikian, Iran sebenarnya juga menggunakan konsep negara-bangsa untuk menegakkan eksistensinya sebagai sebuah negara. Arkoun menyayangkan sikap Khomeini tersebut yang tidak memperlakukan Islam sebagai agama yang dipikirkan kembali dalam rangka pengetahuan kontemporer. Khomeini justru menggunakan Islam sebagai kekuatan mitologis, sosial, historis untuk kepentingan politis. Secara sederhana, akhirnya kalau diperhatikan secara seksama dari masa Nabi sampai pada masa kontemporer, hubungan otoritas dan kekuasaan politis dalam Islam mengalami pasang surut. Pada masa Nabi hubungan itu menyatu dan tercermin pada diri Nabi. Hubungan mulai sedikit merenggang pada masa al-Khulafa' al-Rashidun dan ketegangan semakin meningkat pada masa dinasti Umayyah dan 'Aubasiyyah. Pada masa modern, hubungan itu merenggang, tetapi juga sekaligus menyatu. Merenggang karena legitimasi kekuasaan tidak lagi berasal dari otoritas transendental, melainkan dari tindakan penguasa yang mengaku berdaulat. Hubungan keduanya menyatu jika sekularisme yang dikandungi negara-bangsa tidak dipandang sebagai pemisahan sederhana antara lapangan spiritual dan duniawi. Oleh karena itu, sekularisme adalah persoalan berikut yang mendapat perhatian Arkoun dalam kaitannya dengan hubungan antara otoritas dan kekuasaan pada era modern.

Persoalan sekularisme dan perdebatan panjang yang menyertainya itu jika dirunut ke belakang berasal dari pandangan-dunia yang menegaskan bahwa Islam tidak menerima segala bentuk sekularisme. Menurut Arkoun, pandangan-dunia itu perlu dipertimbangkan kembali dengan meninjau ulang batasan-batasan konstitusi yang tersakralkan dalam berbagai pemerintahan yang berlaku dalam masyarakat Muslim. Arkoun di sini ingin menekankan bagaimana suatu sistem ideologi tertentu dibentuk, diperkenalkan dan kemudian diterima seolah-olah sistem ideologi itu merupakan manifestasi dari wahyu Tuhan. Menurut Arkoun, yang menolak sekularisasi sesungguhnya bukan Islam yang diwahyukan Allah, tetapi tidak lebih merupakan ideologisasi wahyu Allah dalam rumusan-rumusan ortodoksi. ${ }^{32}$ Bagaimana kita bisa berbicara secara pas tentang sekularisme ketika kita tidak mempunyai teori suci yang dapat diandalkan. Bagaimana kita berhadapan dengan hal-hal suci, spiritual dan transenden ketika kita diharuskan untuk menyadari bahwa seluruh kosa kata itu sudah menjadi subjek yang terpengaruh historisitas? Orang dapat mengatakan bahwa nilai-nilai ini telah dieliminir atau disalahinterpretasikan lewat kemenangan kekuasaan material, tetapi pada sisi 
yang lain siapa yang mampu peduli terhadap kesadaran palsu, dogmatisme dan fanatisme religius yang dibangun selama berabad-abad oleh kontrol religius negara?

Orang dapat juga mengatakan tentang religi sekuler, ideologi universal baru dan dominan (liberalisme, sosialisme, kapitalisme) yang digunakan dan dipraktikkan sebagai religi dengan institusi respektif, organisasi ekonomi, perayaan, ritual dan sistem pengetahuan yang mereka miliki. Inilah argumentasi kuat yang oleh kultur modern belum diemansipasikan dari batasan-batasan mitologi dan ideologi yang mengkondisikan kultur-kultur tradisional. ${ }^{33}$ Dalam berbagai hasil observasi, masyarakat Muslim dapat merevisi ide-ide tentang tempat sekularisme dalam Islam dan posisi regim penguasa Islam yang berkaiatan dengan sekularisme. Sejak kolonialisasi, masyarakat Muslim mengadopsi semua atribut materi modernisasi. Keterikatan total ini merupakan alasan sesungguhnya bagi apa yang disebut dengan gerakan fundamentalis yang mengklaim menerapkan suatu hukum dan pengajaran Islam yang integral. Gerakan ini ternyata dalam kehidupan sehari-harinya juga sekuler, termasuk profesi dan kebutuhan dasarnya. Dengan demikian, masa depan sekularisme dalam Islam secara esensial tergantung pada difusi besar-besaran atau yang Arkoun sebut sebagai modernitas intelektual.

Dalam konteks ini, kevakuman kultural merupakan sebab dominan bagi tidak dapatnya sekularisme berkembang dalam virtualitasnya yang positif. Oleh karena itu, Arkoun mengusulkan delapan ringkasan pokok pikiran untuk disoroti sebagai usaha dekonstruksi sejarah pemikiran Islam, yaitu (1) sekularisasi tercakup dalam al-Qur'an dan pengalaman Madinah, (2) negara Umayyah dan Abbasiyah merispakan model sekularis. Teorisasi ideologi yang dibuat oleh para ahli hukum merupakan suatu produksi yangberkenaan dengan lingkungan saat itu, penutupan terhadap realitas historis dan politis. Teorisasi ini dalam banyak kasus dibangun dalam suatu epistemologi yang ketinggalan zaman, (3) kekuatan militer sejak awal memainkan peran menentukan dalam kekhalifahan, kesultanan dan kemudian pada apa yang dikenal dengan bentuk pemerintahan Islam, (4) Usaha-usaha untuk rasionalisasi sekularisme yang de facto ada dalam masyarakat dan untuk membangun sikap sekuler perlu dilakukan oleh para filosof. Hal ini merupakan satu kondisi untuk perangkulan sikap filsafat dalam pemikiran Islam, (5) bentukbentuk Islam ortodoks (Sunni, Shi'i, Khariji) merupakan ungkapan dari berbagai seleksi yang sewenang-wenang karena telah menggunakan ideologi dan

Ulul Albab, Vol. 6 No. 1, 2005 
memperkenalkan bahwa bentuk-bentuk Islam ortodoks itu merupakan agama yang sebenarnya, dalam arti agama yang sesungguhnya dikehendaki oleh Allah, (6) seluruh status religius, sakralitas dan wahyu harus dikaji ulang dalam cahaya epistemologi modern, (7) regim politik yang terdapat dalam masyarakat Muslim setelah bebas dari cengkeraman kolonial secara de facto sekuler dan dikendalikan oleh paradigma-paradigma Barat dan (8) pendekatan filsafat yang dikenal dengan laicite (keawaman), sebagai suatu sumber dan ruang kebebasan intelektual untuk membangun suatu teori dan praktik intelektual, merupakan tugas yang juga dikerjakan dalam amsyarakat Barat saat ini. ${ }^{34}$ Delapan poin tersebut merupakan bagian penting dari suatu program besar kebangkitan kembali Islam dalam rangks memberikan jawaban mendesak terhadap tuntutan masyarakat Muslim.

\section{E. Penutup}

Mengakhiri tulisan ini perlu ditegaskan kembali bahwa otoritas merupakan persyaratan dalam melegitimasi kekuasaan politik. Otoritas dalam kultur Islay terkondisikan lewat tradisi skriptural yang terlindungi melalui postulat bahwa para sahabat itu maksum dan secara hati-hati menyampaikan teks otentik dan fakta historis yang berkaitan dengan Nabi secara keseluruhan. Generasi berikutnya menyampaikan tradisi yang telah dipelajari dari sahabat dan hasilnya dikumpulkan dalam mushaf dan hadits. Para ulama' mujtahid menambahkan kepada korpus itu hukum-hukum suci yang terelaborasi berdasarkan prinsip dan metode yang diberikan dalam usul al-figh. Totalitas korpus yang terpercaya itu terkontrol oleh tradisi sehingga para penguasa Muslim akan terlegitimasi pemerintahannya sejauh ia melindungi dan menerapkan tradisi tersebut.

Problem sekularisme yang diusung oleh bentuk negara-bangsa yang berkembang pada era modern ternyata telah membawa perubahan pada konsep otoritas dan legitimasinya terhadap pemerintahan Islam yang sudah mentradisi. Jika dalam sejarahnya para penguasa Muslim selalu memperjuangkan otoritas transendental sebagai legitimasi pemerintahan, maka pada era modern ini sekularisme dan nasionalisme telah menggantikan kedudukan otoritas transendental itu dalam bentuk negara-bangsa. Dalam konteks ini, dialektika antara menerima atau menolak sekularisme dalam rangka mempertahankan otoritas menjadi persoalan besar yang harus dipecahkan melalui modernitas intelektual. 


\section{Endnotes}

Proses kreativitas terletak pada kombinasi yang mengagumkan antara keberhasilan aksi politik, sosial dan kultural dengan sublimasinya atas diskursus religius yang spesifik dengan penggunaan sebuah sistem metafora yang besar dan terorganisir. Pengikut Nabi dipadukan dalam pergerakan kreatif dan ditegakkan oleh simbolisasi yang kaya. Lihat Mohammed Arkoun, "The Concept of Authority in Islamic Thought," dalam Klaus Ferdinand dan Mehdi Mozaffari, Islamic, State and Society (Copenhagen, Scandinavian Institute of Asian Studies, 1998), 57.

2 Meskipun sumber-sumber utama Islam (al-Qur'an dan Hadis) tidak banyak berbicara tentang pemerintahan dan negara, isu pertama yang dihadapi komunitas Muslim sepeningal pemimpin formatifnya, Nabi Muhammad, pada $632 \mathrm{M}$ adalah masalah pemerintahan dan cara memilih pengganti (khalifah) Nabi. Oleh karena itu, sejak awal kaum Muslim harus berinovasi dan berimprovisasi mengenai bentuk dan sifat pemerintahan. Komunitas Muslim tak pelak lagi berhubungan dengan perumusan teori politik yang akhimya melahirkan polemik berkepanjangan seputar negara Islam. Lihat keterangan lebih lanjut Najih N. Ayubi, Political Islam: Religion and Politics in the Arab World (New York: Wamer Books, 1991).

Bassam Tibi, Krisis Modern dalam Peradaban Islam, terj. Yudian W Aswin (Yogyakarta: TiaraWacana, 1994), 60.

4 Telaah singkat atas persoalan legitimasi bermanfaat di sini. Abu Bakr dan 'Umar, dua khalifah pertama, menekankan aspek legitimasi dengan memakai tiga prinsip: Shura (musyawarah), 'Aqd (kontrak penguasa-rakyat) dan Bay'ah (sumpah setia). Metode ini digunakan dalam mengangkat pengganti mereka, 'Uthman. Akan tetapi, shura berangsur-angsur diabaikan, kemudian 'aqd dan bay'ah setelah berdirinya dinasti Umayyah yang semi aristokratis. Selama era 'Abbasiyyah, pertentangan antara legitimasi pemerintah dan kesatuan umat mengemuka. Sejak itu, hukum yang ditekankan dalam teori adalah otoritas khalifah sebagai simbol politik dan kesatuan umat sebagai basis manusia. Ketika otoritas pemimpin dan kesatuan umat tidak lagi utuh dan mutlak, titik beratnya bergeser ke shari'ah sebagai basis kesatuan ideologis karena kesatuan politik dan manusia tidak lagi dapat dicapai. Sejak abad ke-12, sumber utama legitimasi dinasti-dinasti regional adalah membela negeri Muslim secara militer terhadap kaum penyerbu. Hal tersebut tampaknya memberikan gambaran bentuk baru legitimasi: bahwa dinasti kesultanan regional itu terlegitimasi pemerintahannya sepanjang mampu menghadapi musuh asing. Lihat Taqi al-Din Ahmad ibn Taymiyyah, al-Siyasah al-Shar 'iyyah (Beirut: Dar al-Mashriq Publisher, 1983).

5 Fenomena hubungan antara Islam dan politik tidak selalu harus dipahami sebagai repolitisasi Islam. Fenomena tersebut dapat dibaca sebagai hubungan antara dua 
variabel yang saling berinteraksi yang tidak secara niscaya membawa ke pembekuan ideologis. Dalam hal ini, Islam dapat mengambil peranan sebagai pembawa alternatif prinsip-prinsip dasar berupa etika dan moral. Lihat M. Din Syamsuddin, "Usaha Pencarian Konsep Negara dalam Pemikiran Islam,” Ulumul Qur'an, 4 (April-1993), 2.

6 Mohammed Arkoun lahir tanggal 1 Pebruari 1928 di Taourirt-Mimoun Kabilia Aljazair, sebuah wilayah yang dikuasai Perancis sejak 1830. Di tengah kecamuk perang kemerdekaan (1954-1963), Arkoun melanjutkan studi di Universitas Sorbonne Paris dan terhitung sejak saat itu dia menetap di Perancis. Lihat J.H. Meuleman, "Nalar Islami" Ulumul Qur'an, 4 (April-1993), 93.

7 Arkoun dalam menyiapkan teori tentang otoritas (yang komprehensif dan objektif) mengandalkan referensi filsafat sebagai sebuah evaluasi modern. Menurutnya, ada tiga alasan yang diajukan, yaitu (1) referensi filsafat telah dihilangkan oleh semua ahli hukum yang memberikan sumbangan teori otoritas dalam Islam. Hal itu koheren dengan persaingan yang terjadi antara kaum ahli fiqh dan filosof yang kemudian kemenangan ada di pihak ahli fiqh (kaum ortodoks), (2) kritisisme filsafat telah dihilangkan oleh para Orientalis sebagai sesuatu yang dianggap tidak relevan dengan pendekatan naratif dan filologi mereka, dan (3) hanya dengan filsafat yang selalu mempertanyakan dapat diperoleh kesempatan untuk melampaui deskripsi tentang doktrin yang semata-mata teknis dan dicapai kepastian ideologis yang secara implisit tampak dalam perbincangan para peneliti Barat. Poin ini memiliki signifikansi khusus dalam perdebatan antara kebangkitan hukum Islam dan prosedur-prosedur legislasi modern, yang telah berjalan bertahun-tahun. Lihat Arkoun, The Concept, 54.

Mohammed Arkoun, "Madkhal li Dirasah al-Rawabit bayna al-Islam wa al-Siyasah," dalam Mohammed Arkoun, al-Fikr al-Islami: Qira'ah 'Ilmiyyah, terj. Hashim Salih (Beirut:Markazal-Inma' al-Qawmi, 1987), 143.

9 Ibid.; Lihat juga Mohammed Arkoun, "Wewenang dan Kekuasaan dalam Islam," dalam Mohammed Arkoun, Nalar Islami dan Nalar Modern: Berbagai Tantangan dan Jalan Baru, terj. Rahayu S. Hidayat (Jakarta: INIS, 1994), 225.

Ibid., 147; Arkoun, Madkhal, 148.

11 Ibid.

12 Ibid., 148.

13 Leonard Binder, guru besar ilmu politik pada Universitas Califomia, memasukkan Arkoun sebagai kategori pemikir eklektis. Dalam banyak karya ilmiahnya, Arkoun memiliki kecenderungan Strukturalisme, Pasca-Strukturalisme dan Dekonstruksi dengan gaya pendekatan pada analisis linguis. Leonard Binder, Islamic Liberalism (Chicago: University of Chicago Press, 1988), 161-169. 
14 J.H. Meuleman, "Pengantar," dalam Mohammed Arkoun, Nalar Islami dan Nalar Modern: Berbagai Tantangan dan Jalan Baru, terj. Rahayu S. Hidayat (Jakarta: INIS, 1994), 225.

is Dari Ricoeur, Arkoun memperoleh pandangan tentang mitos, dari Foucault tentang istilah episteme, diskursus dan arkeologi, dari Derrida mengenai semiotika. Lihat J.H. Meuleman, Nalar Islami, 99-101.

16 Ibid.

17 Mohammed Arkoun, "The Concept of Authority in Islamic Thought," dalam Klaus Ferdinand dan Mehdi Mozaffari, Islamic, State and Society (Copenhagen, Scandinavian Institute of Asian Studies, 1998), 55. Lihat juga Mohammed Arkoun, "Mafhum al-Siyadah al-'Ulya fi al-Fikr al-Islami," dalam Mohammed Arkoun, al-Fikr al-lslami, 159.

18 Meuleman, "Pengantar," dalam Mohammed Arkoun, Nalar Islami, 33.

19 Al-Qur'an, 114: 1.

20 Ibid., 96: 1.

21 Ibid., 17: 107.

22 Arkoun, Madkhal, 148.

23 Mohammed Arkoun, Arab Thought (New Delhi: S. Chand and Company LTD, 1988), 81.

24 Ibid.

25 Arkoun, Madkhal, 147.

26 Arkoun, The Concept, 58.

27 Ibid., 60.

28 Ann K.S. Lambton, State and Government in Medieval Islam (Oxford: Oxford University Press, 1981), 264.

29 Ibid.

30 Arkoun, The Concept, 63.

31 Sebagai pelengkap observasi singkat ini, perlu disebutkan otoritas menurut para orator dan penyair, khususnya pada masa dinasti Ummayyah dan dinasti 'Abbasiyyah yang pertama. Negara baru membutuhkanbantuan dari orator sebagaimana kebutuhan dukungan yang kuat dari kharisma seorang religious-minded seperti Hasan al-Basri. Sejarah mencatat bahwa peranan ini dimainkan oleh orator seperti Jarir, Farazdaq, alAkhtal, Kuthayyir, Bashshar dan lainnya. Otoritas literasi estetik digunakan sebagai dukungan ideologis, bersama-sama dengan otoritas teks dan kharismatik. Ibid. 
32 Ibid., 70.

33 Ibid., 71.

34 Ibid., 72-73.

\section{Bibliography}

Arkoun, Mohammed. Arab Thought. New Delhi: S. Chand and Company LTD, 1988.

Arkoun, Mohammed. "Madkhal li Dirasah al-Rawabit bayna al-Islam wa alSiyasah," dalam Mohammed Arkoun. al-Fikr al-Islami: Qira'ah 'Ilmiyyah. Terj. Hashim Salih. Beirut: Markaz al-Inma' al-Qawmi, 1987.

Arkoun, Mohammed. "Mafhum al-Siyadah al-'Ulya fi al-Fikr al-Islami," dalam Mohammed Arkoun, al-Fikr al-Islami: Qira'ah 'Ilmiyyah. Terj. Hashim Salih. Beirut: Markaz al-Inma' al-Qawmi, 1987.

Arkoun, Mohammed. "The Concept of Authority in Islamic Thought," dalam Klaus Ferdinand dan Mehdi Mozaffari. Islamic, State and Society. Copenhagen, Scandinavian Institute of Asian Studies, 1998.

Arkoun, Mohammed. "Wewenang dan Kekuasaan dalam Islam," dalam Mohammed Arkoun. Nalar Islami dan Nalar Modern: Berbagai Tantangan dan Jalan Baru. Terj. Rahayu S. Hidayat. Jakarta: INIS, 1994.

Ayubi, Najih N. Political Islam: Religion and Politics in the Arab World. New York: Warner Books, 1991.

Binder, Leonard. Islamic Liberalism. Chicago: University of Chicago Press, 1988. ibn Taymiyyah, Taqi al-Din Ahmad. al-Siyasah al-Shar'iyyah. Beirut: Dar alMashriq Publisher, 1983.

Lambton, Ann K.S. State and Government in Medieval Islam. Oxford: Oxford University Press, 1981.

Meuleman, J.H. "Pengantar," dalam Mohammed Arkoun, Nalar Islami dan Nalar Modern: Berbagai Tantangan dan Jalan Baru. Terj. Rahayu S. Hidayat. Jakarta: INIS, 1994. 
Meuleman, J.H. 'Nalar Islami”' Ulumul Qur'an, 4 (April-1993), 93-105..

Syamsuddin, M. Din. "Usaha Pencarian Konsep Negara dalam Pemikiran Islam," Ulumul Qur'an, 4 (April-1993), 2-9.

Tibi, Bassam. Krisis Modern dalam Peradaban Islam. Terj. Yudian W Aswin. Yogyakarta: Tiara Wacana, 1994. 